\title{
Analysis of Scraps Cause of Noodle Production in PT. Indofood CBP Success Makmur Tbk. using Fault Tree Analysis Methods
}

\author{
Diana Puspita Sari ${ }^{1,}$, Sela Tri Parwati ${ }^{1}$, Dyah Ika Rinawati ${ }^{1}$ and Purnawan A. Wicaksono ${ }^{1}$ \\ ${ }^{1}$ Industrial Engineering Department, Faculty of Engineering, Diponegoro University \\ J1. Prof. H. Soedarto, SH, Tembalang, Semarang, Indonesia
}

\begin{abstract}
Food industry can survive when they can improve the productivity to meets the customer needs. PT Indofood CBP Sukses Makmur Noodle Division is one of food industry in Indonesia. Based on the production data of PT Indofood CBP Sukses Makmur Noodle Division Cibitung plant 3, found that the number of scrap noodles is almost always above the company minimum limit. This condition causes the company losing a profit of about 1.3 million per day per line. Based on these problems, this study aims to find the root causes of scraps of noodles production, then provide the advice on prevention of high amount of scrap of noodle production. The method used in this research is Fault Tree Analysis (FTA) and Five Step Plan analysis. The result of FTA analysis shows the cause of the high scrap of noodle production is the number of blocks noodles that fall as it passes through the conveyor in the frying and packing process, and because the operator less observant in connects the spice etiquette, less thorough to set the speed of the autoloader engine, less careful in case of handling the noodles. Suggested solutions include the implementation of 'seiri' by sorting reject spice oil and spices; 'seiton' by placing rolls of etiquette in easily reach place by the operator; 'seiko' by discarding etiquette, spices, and spiced oils into their respective containers; 'seiketsu' which is the division of responsibility for cleanliness of each operator; and 'shitsuke' ie routine briefing based on schedule.
\end{abstract}

Keywords: Fault Tree Analysis (FTA), Five Step Plan, Scrap

\section{Introduction}

As one of the industrial companies, especially food sector companies in Indonesia, PT Indofood CBP Sukses Makmur Noodle Division should always improve all aspects of the

Corresponding author: dpsari.01@gmail.com 
company in order to improve the quality. Feigenbaum explains that quality is the overall characteristic of both products and services [1]. Juran in Kaban [2] describes the definition of quality as a package of features and characteristics of products that provide satisfaction for consumers, conformance to requirement that is something that has been standardized, conformity with the needs of the market, or the state of the product of the physical, nature, and function so that it can meet the wants and needs of consumers in accordance with the value that has been issued. The product is said to be of quality if the product has a suitable use for itself. Another definition says quality is the goods or services that can raise the user's status, others say goods or services that benefit the user (measure of utility and usefulness) [3]. The main purpose of quality control is to obtain assurance that the quality of the product or service is produced in accordance with predetermined quality standards by issuing economical or lowest cost [4]. Garvin (1995) suggests eight dimensions or critical categories of quality namely: performance, featured, reliability, conformance, durability, serviceability, aesthetics and perceived quality. A product will be declared qualified by the manufacturer, if the product is in accordance with its specifications [5].

PT Indofood CBP Sukses Makmur Noodle Division is the largest noodle division company in Cibitung. The production process involves making noodles from raw materials in the form of wheat flour to noodle blocks of noodles in the packaging of etiquette. The process of producing noodles produces scrap. Scrap is the result of the processing of noodles in the form of dough noodles, exsteam noodles, fractions of noodles, broken noodle blocks, and noodle blocks that are not in accordance with the standards so it is not feasible to proceed to the packaging and distribution process. From the various stages of this noodle making from raw materials to noodle blocks, of course there is activity/something that does not give added value, has no benefits, and also result in waste. Waste in the production process is grouped into 7, i.e.: excessive production, stock, damage, ineffective transport/transfer, unnecessary movements and waiting (Pramono, 2013).

Based on production data of PT Indofood CBP Sukses Makmur Noodle Division Plant 3, it is found that the number of scrap noodles is almost always above the minimum limit set by the company. Analysis of scrap production data of December 2016, obtained the value that every day production process produces the amount of scrap that is above the company standard limit (0.3), with an average percentage of 0.38 . This causes the company losing a profit of about 1.3 million, or more than $1 \%$ of the profits received by the company per line per day. This scrap case becomes very detrimental to the company because the amount of scrap that exceeds the standard of PT Indofood and resulted in the company losses 2, 8 million in one month. Therefore it is necessary to do an analysis to determine the factors that cause a lot of scrap that arises.

The environmental and operation analysis of a process, to find solutions to existing problems can be explained by the Fault Tree Analysis (FTA) method. FTA is also called an error tree. Baig et al [6] explains that FTA is a very effective tool for assessing risk especially in complex systems. The advantages of the FTA is to begin solving the problem of the top event selected by the user as interest and the tree to be identified the root cause. The objectives of this research are to identify factors causing high number of normal noodle scrap at line 31 plant 3 PT Indofood CBP Sukses Makmur Cibitung, and to analyze the factors causing high number of scrap. From various factors that have been determined then done suggestions to PT Indofood as an effort to reduce the number of scrap that arises.

\section{Research Methods}


A preliminary study was conducted by collecting secondary data of scrap at line 31 plant 3 production of PT Indofood Cibitung. Based on these data, the amount of scrap production is almost always above the standard limit of the company. Then analyzed based on scrap production data of December 2016, the average percentage of scrap production amounted to 0.38 is above the average standard of 0.3 percent.

FTA diagramming begins by interviews and brainstorming with section manager, shift section manager, section and staff in the production and quality control. Based on the data then performed an analysis using the FTA method. Roberts and Vessely [7] explained FTA chart described the logical relationships of the underlying causes of the problem. This error tree is a graphical representation of parallel errors and combinations of errors as the cause of the errors that exist on it. FTA uses symbols to explain the type of event that causes the problem. The symbols used in the FTA are described in table 1. Gharahasanlou et al [8] explains that the FTA diagram uses the "AND" and "OR" gate as logical operators. At the "AND" gate the output event occurs only when the event occurs. While on the "OR" gate event output occurs if one event occurs.

Table 1. Meaning of FTA Symbols

The Meaning
Basic Event, basic fault initiation that does not require further development
Conditionally Evently, specific conditions that can be applied to various logic
gates
Undevelopment Event, event that cannot be developed anymore because the
information is not available
External Event, the expected event appears
AND gate, the error arises because all input problems occur together
OR gate, the error arises from one of the input problems that occur

The six basic steps often used in developing FTA [8] includes understanding of system configuration, build logic model, qualitative evaluation of the logical model, analysis of equipment failures and obtaining basic research data, quantitative evaluation of the logical model and proposed improvement.

The FTA making process begins with the definition of the problem and then proceeds to study the existing system and describes it in graphical form of the error tree. The steps taken in the manufacture of FTAs are: (1) Determining the top event of the problem, top event is the determination of the main problem in non-conformity that occur in a system, (2) Determination of limits used in FTA, learn the system by finding out Standard Operational Procedures (SOPs) or anything related to the company's mechanisms that maybe affect the error and (3) Designing FTA, FTA charting is made by reconsidering the various things that are considered as the cause of the problem with various information that has been obtained in the previous stage [7]:

Based on this FTA chart, the system logical relationship between the impacts and causes can be known. The main causes of problems can be found based on qualitative and quantitative analysis on the fault tree. This provides a reliable basis for determining how 
precautions are needed to prevent problems or to achieve goals. $\mathrm{Hu}$ [9] explains that the FTA is both a practical and comprehensive method for risk analysis and problem prevention, which is used in identification, prediction, evaluation and control. From the various events that are the main cause of the high number of scrap, then given solution suggestion using Five Step Plan method. This method aims to structuring and maintenance of work areas. Then this concept is called the Kaizen Concept [10], which consists of:

1. "Seiri" (Brief-Circle-Order). Seiri is a first step to run the $5 \mathrm{~S}$ culture. Seiri has the intention to throw/sort/get rid of the goods, files that are not used again to the disposal.

2. "Seiton" (Neat-Arrange-Neatness). After sorting all items or files that are not used anymore, make sure everything must be placed according to the position set, so it is always ready to use when needed.

3. "Seiso" (Clean-Sweep-Clean). After being neat, the next step is cleaning the workplace, work space, equipment and work environment.

4. "Seiketsu" (Care-Uniform-Consolidation). This stage takes care of the three previously executed stages on a regular basis. This stage can also be called the stage of treatment, is the standardization and consistency of each individual to perform the previous stages.

5. "Shitsuke" (Diligent-Always-Discipline-Habituation). Maintenance of personal discipline includes a habit and maintenance of an already running $5 \mathrm{~S}$ program.

\section{Discussions}

\subsection{Designing of Fault Tree Analysis (FTA)}

The first stage is done FTA analysis by identifying top event. Problems encountered in normal noodle production process PT Indofood CBP Sukses Makmur Tbk. Cibitung is the high number of scrap noodles production. The number of scraps of this noodle product is very high beyond the company standard limits. The problem of high amount of scrap is caused by various factors such as technical factor and human factor.

The second stage is determination of FTA limits. Limitations in this FTA are: normal noodle for AB type and under normal conditions. The third stage is creation of FTA. At this stage the FTA chart is made by reconsidering the various causes of scrap. From the FTA chart, various events are found at the bottom of the chart which is the basic event and undevelopment event as the root cause of scrap. The amount of scrap produced by normal noodle production at line 31 is triggered by two things, that is, because of the scrap caused at the frying stage and the unsuitable noodle block (at the packing stage). Of the two things that cause the occurrence of scrap, both occur simultaneously. Because if the frying event does not occur simultaneously with an unsuitable noodle block it will not cause a high number of scrap noodles.

The unsuitable event block of noodles is caused by 2 events, the noodle blocks of noodles affected by the end sealer event and noodle blocks of noodles that fall from the conveyor event do not occur simultaneously. This means that if one event of the noodle block is exposed to end sealer event and noodle blocks are not suitable event to occur individually then this will still cause a high amount of scrap. Event noodle blocks exposed end sealer caused by autoloader is jammed event and speed of autoloader event not match which do not coincide. From each event that happens separately then scrap can still cause 
high number of noodle scraps. Event noodle blocks fell from the conveyor caused by 3 events that occur separately. The three events are event of operator handling that are not good, the event of noodle blocks that hit the blower sensor, and the event of a gap in the conveyor connection that causes the noodle blocks to fall. The FTA chart of the causes of the high number of normal noodle production scraps in line 31 of PT Indofood's production plan 3 is illustrated in Figure 1. Based on the FTA analysis, table 2 shows the recapitulation of factors causing the occurrence of scrap.

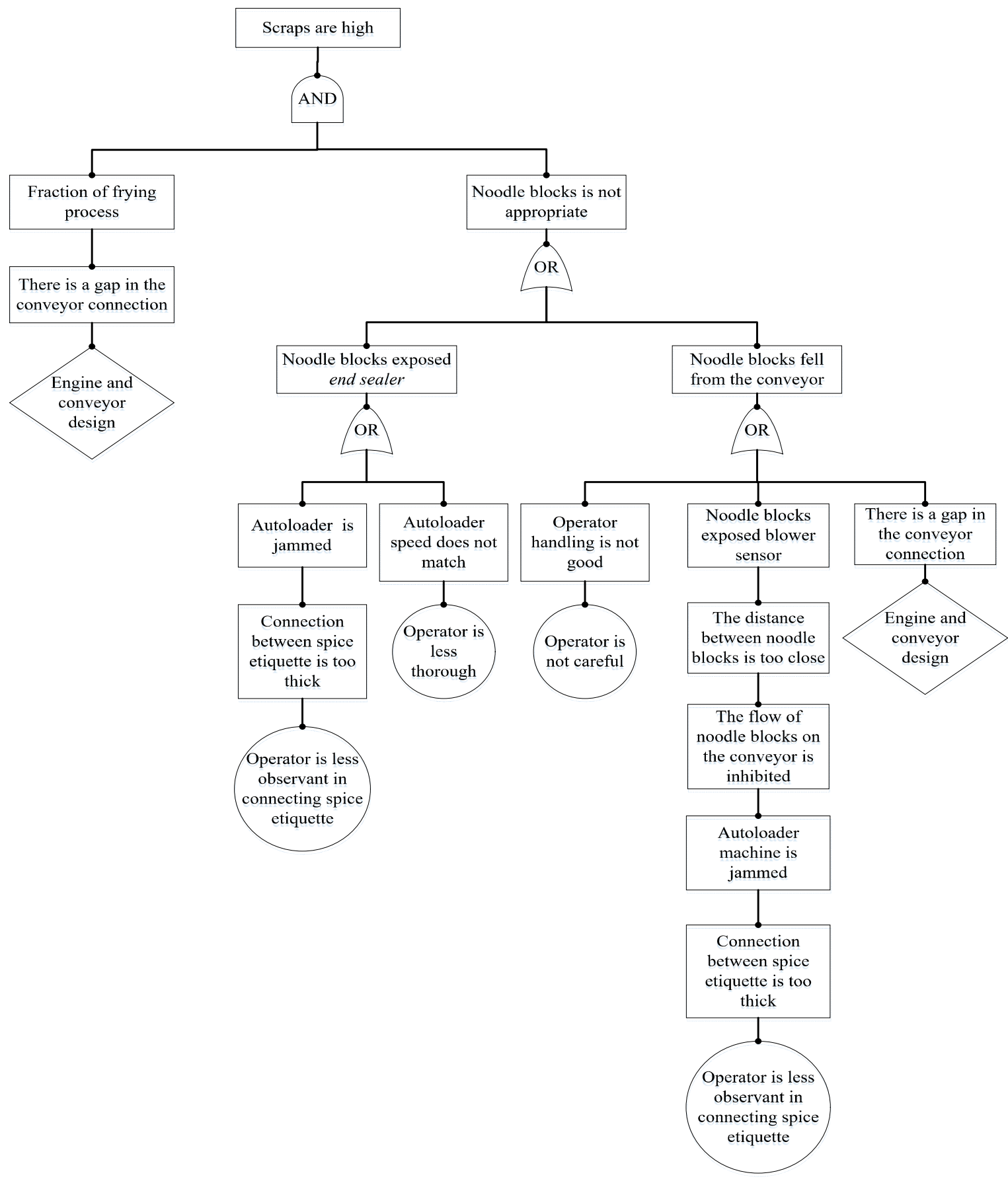

Figure 1. Fault Tree Analysis of Noodle Scrap Causes 


\subsection{Recommendation of Prevention using Five Step Plan}

At this stage of giving recommendation to reduce the amount of scrap production. Based on the FTA chart, the cause of the number of scrap noodles at line 31 is preceded by the operator who is less observant, less thorough and less careful. Suggestions that can be given to the company, especially the production using the five step plan are:

1. Seiri (Sorting)

The implementation of 'seiri' is sorting spice oil and spices that are rejected by the seasoning operator, then removing or disposing of spice oil or spices that reject it to the dump. So the seasoning oil and spices on the desk near the operator are spice oil and spices that do not leak (good). This will certainly increase the concentration of operators.

2. Seiton (Setup)

The implementation of 'seiton' is done with the aim that the operator can find the goods easily, so the time becomes more effective. Implementation is by putting the reels of etiquettes in a corner line near the sealer, so the sealer operator is easy to take it.

3. Seiko (Hygiene)

The implementation of 'seiko' can be done by removing the defective etiquette into the etiquette container, and disposing of damaged spices or spice oil or reject as soon as possible. It is aimed to avoid the accumulation of goods that are not used in the production process in the operator's work area, so the operator feels more comfortable. Hygiene supervision is required in the work area operator. Operators also have to get used to cleaning the workplace. In addition to maintaining cleanliness and production quality, this can also improve time efficiency and can reduce the chance of damaged machines.

4. Seiketsu (Care)

The implementation of 'seiketsu' is done by dividing the responsibility of each operator on the cleanliness in their respective work area. From the management side, especially the shift section as the lower level management that always deal directly with the operator also must always provide control and supervision to the operator.

5. Shitsuke (Habituation)

Implementation of 'shitsuke' can be done with the implementation of each briefing before shift begins by the related shiftsection. This will be a habituation for the operator to have a better atmosphere because the operator will prepare yourself early. Implementation of ISO training related to the cleanliness of the environment and the use of Personal Protective Equipment (PPE) with routine according to schedule.

Table 2 Recapitulation of Factors Causing the Incidence of Noodle Scrap

\begin{tabular}{cll}
\hline No & \multicolumn{1}{c}{ Cause } & \multicolumn{1}{c}{ Description } \\
\hline 1 & $\begin{array}{l}\text { Engine design } \\
\text { and conveyor } \\
\text { (on conveyor }\end{array}$ & $\begin{array}{l}\text { Noodles (in noodle blocks and crumb noodles form) fall from the } \\
\text { conveyor connection after the frying process. The vibrating } \\
\text { frying) }\end{array}$ \\
& $\begin{array}{l}\text { conveyor design has the purpose to drain the noodles that have } \\
\text { just passed the qualifier. The connection between the qualifryer } \\
\text { conveyor and the cooling conveyor which has a large gap and has } \\
\text { a working mechanism to reverse the noodle block. in this case the } \\
\text { design of the engine and conveyor becomes undevelopment event } \\
\text { because there is no data that allows related to this matter. }\end{array}$
\end{tabular}




\begin{tabular}{|c|c|c|}
\hline No & Cause & Description \\
\hline 2 & $\begin{array}{l}\text { The operator is } \\
\text { less observant in } \\
\text { connecting spice } \\
\text { etiquette }\end{array}$ & $\begin{array}{l}\text { The thickness of the connection resulted in the autoloader engine } \\
\text { jammed. Spice etiquette connections that are too thick also over } \\
\text { time can make the machine damaged. Therefore, the need for } \\
\text { handling of this basic event. }\end{array}$ \\
\hline 3 & $\begin{array}{l}\text { The operator is } \\
\text { not thorough }\end{array}$ & $\begin{array}{l}\text { This is related to the wrong set of autoloader engine speed, so it } \\
\text { does not sync with the speed of the conveyor. If there is a wrong } \\
\text { setting speed of the autoloader, it causes during the running, then } \\
\text { the noodle blocks passing through this stage will be exposed to } \\
\text { the end sealer. Therefore, the need for anticipation in order to } \\
\text { avoid the basic event is happening. }\end{array}$ \\
\hline 4 & $\begin{array}{l}\text { Operator is not } \\
\text { careful }\end{array}$ & $\begin{array}{l}\text { This is related to operators handling that are less careful, resulting } \\
\text { in many noodle blocks of noodles that fall to the floor (reject). } \\
\text { Basic event is also associated with the mental atmosphere of } \\
\text { workers. If the operator is hurried then lead to higher disparity. } \\
\text { Therefore, the need for handling to minimize scrap generated by } \\
\text { this basic event. }\end{array}$ \\
\hline 5 & $\begin{array}{l}\text { Operator is less } \\
\text { observant in } \\
\text { connecting spice } \\
\text { etiquette }\end{array}$ & $\begin{array}{l}\text { Rough connections resulted in the autoloader engine jammed, } \\
\text { resulting in blocked noodle blocks. Therefore, the need for } \\
\text { prevention of basic event is not the case. }\end{array}$ \\
\hline 6 & $\begin{array}{l}\text { Machine and } \\
\text { conveyor design } \\
\text { (packing } \\
\text { conveyor) }\end{array}$ & $\begin{array}{l}\text { Noodles (in the form of noodle blocks and crumb noodles) fall on } \\
\text { the packing conveyor. However, unavailability of data that can be } \\
\text { used causes this cause to be an undevelopment event }\end{array}$ \\
\hline
\end{tabular}

\section{Conclusion}

The high number of scrap is caused by engine and conveyor design (on frying and packing conveyor), operator less observant, less precise and less careful. Cause of high number of scrap are noodle blocks and crumbs of noodles falling from the conveyor joint after the frying process; the roughness of the connection resulted in the autoloader engine jammed, speeds of the autoloader engine and conveyor does not sync, operators handling that are less cautious, resulting noodle blocks of noodles that fall to the floor, the roughness of the connection resulted in the autoloader engine jammed, causing the blocks to be inhibited; and noodle blocks and crumbs noodles fall on the packing conveyor.

The preventive solution using the Five Step Plan include the implementation of $5 \mathrm{~S}$ by sorting spice oil and spices rejected, then remove or remove the spice oil or spice that reject it to the dump (seiri), placing the reels of etiquettes in a corner near the sealer, so the operator can easily pick it up (seiton), removing the defective etiquette into the etiquette container, and disposing of damaged spices or spice oils or rejects as soon as possible (seiko), dividing the responsibilities of each operator over cleanliness in their respective work areas (seiketsu), and briefing before the shift begins by the related shift section and implementation of ISO cleanliness training and the use of Personal Protective Equipment (shitsuke). 


\section{References}

1. Ariani, D. W. (2004). Pengendalian Kualitas Statistik. Yogyakarta: Andi Offset.

2. Kaban, R. (2014). Pengendalian Kualitas Kemasan Plastik Pouch Menggunakan Statistical Procces Control di PT Incasi Raya Padang. Jurnal Optimasi Sistem Industri, $13(1), 518-547$.

3. Gasperz, V. (2001). Metode Analisis untuk Peningkatan Kualitas. Jakarta: Gramedia Pustaka Utama.

4. Assauri, S. (1998). Manajemen Produksi dan Operasi. Jakarta: FE Universitas Indonesia.

5. Juran, J. M. (1998). Juran's Quality Control. New York: McGraw-Hill.

6. Baig, A. A., Ruzli, R., \& Buang, A. B. (2013). Reliability Analysis Using Fault Tree Analysis: A Review. International Journal of Chemical Engineering and Application, 4(3), 169-173.

7. Vessely, W. E., Goldberg, F. F., Roberts, N. H., \& Haasl, D. F. (1981). Fault Tree Handbook. Washington DC: U.S. Government Printing Office.

8. Gharahasanlou, A. N., Mokhtarei, A., \& Khodayarei, A. (2014). Case Study Fault Tree Analysis Failure Cause of Crushing Plant and Mixing Bed Hall at Khoy Cement Factory in Iran. Case Studies in Engineering Failure Analysis, 2(1), 33-38.

9. Hu, Y. (2016). Research on the Application of Fault Tree Analysis for Building Fire. Proceedia Engineering, 135, 524-530.

10. Suwondo, C. (2012). Penerapan Budaya Kerja Unggulan 5S (Seiri, Seiton, Seiso, Seiketsu dan Shitsuke) di Indonesia. Jurnal Magister Manajemen, 1(1), 29-48. 